3 Feinfeld DA, Olesnicky L, Pirani CL, Appel GB. Nephrotic syndrome associated with use of the nonsteroidal anti-inflammatory drugs. Nephron 1984;37:174-9.

Wolters J, Van Breda Vriesman PJC. Minimal change nephropathy and interstitial nephritis associated with diclofenac. Neth $\mathcal{F}$ Med 1985;28:311-4.

5 Finkelstein A, Fraley DS, Stachura I, Feldman HA, Gandy RD, Bourke E. Fenoprofen nephropathy: lipid nephrosis and interstitial nephritis. A possible T-lymphocyte disorder. Am f Med 1982;72:81-7.

(Accepted 15 April 1987)

Departments of Nephrology and Immunology, University Hospital, Maastricht, The Netherlands

G D M BEUN, MD, registrar in internal medicine

K M L LEUNISSEN, MD, registrar in internal medicine

P J C VAN BREDA VRIESMAN, MD, professor in immunology

J P VAN HOOFF, MD, senior registrar in nephrology

Department of Internal Medicine, Saint Laurentius Hospital, Roermond, The Netherlands

W GRAVE, MD, consultant physician

Correspondence to: Dr Leunissen.

\section{Veno-occlusive disease of the liver secondary to ingestion of comfrey}

There is currently considerable interest in alternative medicine and herbal remedies. These treatments are not without risk, however, as illustrated by the following case.

\section{Case report}

A 13 year old boy was admitted in July 1986 for investigation of hepatomegaly and ascites. Three years earlier Crohn's disease had been diagnosed from radiographs showing consistent changes in the terminal ileum and colon and from histological studies of the colon. He was treated with prednisolone and sulphasalazine with benefit. At his parents' request these drugs were discontinued and he was treated with acupuncture and comfrey root, prescribed by a naturopath. Up to 1986 he had been regularly given a herbal tea containing comfrey leaf. The exact quantities of leaves given and frequency of administration are unknown. An exacerbation of his inflammatory bowel disease in 1984 required a further course of prednisolone. In June 1986 he presented with fatigue, diarrhoea, and weight loss and a few weeks later developed fever, abdominal pain, and swelling. He was taking prednisolone and sulphasalazine. He had never taken azathioprine.

On examination he had ascites and tender hepatomegaly but no dehydration, jaundice, or heart failure and no stigmata of chronic liver disease. Sigmoidoscopy showed mildly inflamed, cobblestoned mucosa. He had mild iron deficiency anaemia (haemoglobin $117 \mathrm{~g} / \mathrm{l}$ ) and raised serum bilirubin concentration (26 $\mathrm{mmol} / \mathrm{l}$, normal $<17)$ and aspartate aminotransferase activity $(87 \mathrm{IU} / \mathrm{l}$; normal 6-35). Serum albumin was low at $27 \mathrm{~g} / \mathrm{l}$. The results of the following tests were normal: urea, electrolytes, serum globulin, alkaline phosphatase, complement, plasma viscosity, full coagulation screen, autoantibody profile, and acid haemolysis. Hepatitis B surface antigen and antibodies to hepatitis A were absent as were Epstein-Barr virus and cytomegalovirus. Ascitic fluid protein concentration was $27 \mathrm{~g} / \mathrm{l}$. The inferior vena cava and major hepatic veins were patent on Doppler ultrasound and percutaneous phlebography. Percutaneous liver biopsy showed the thrombotic variant of hepatic veno-occlusive disease (figure). ${ }^{1} \mathrm{He}$ was treated with spironolactone, salt restriction, and bed rest with a good response. His bowel disease remained relatively inactive with treatment with prednisolone and sulphasalazine; at the time of writing he was back at school and tolerably well on his medication.

\section{Comment}

Known or suspected causes of hepatic veno-occlusive disease are systemic lupus erythematosus, alcoholic hepatitis, immune deficiency, azathioprine (in renal transplant recipients), radiotherapy, chemotherapy (especially in bone marrow transplant recipients), and pyrrolizidine alkaloids. ${ }^{2}$ These alkaloids are present in a wide variety of plant species, and those of the genera Heliotropium, Senecio, and Crotalaria are particularly toxic. ${ }^{3}$ Ingestion of plants containing alkaloids in "bush" or herbal teas or as food contaminants is responsible for appreciable numbers of cases world wide. ${ }^{3}$ Only two cases of hepatic veno-occlusive disease as a result of pyrrolizidine alkaloid ingestion have been described in Britain, however, and both patients had ingested imported herbal teas. We think that the only possible causal factor for hepatic veno-occlusive disease in our patient was comfrey, which he had regularly ingested for two to three years; major hepatic vein thrombosis but not veno-occlusive disease has been described in patients with colitis.' The common comfrey, Symphytum officinale, a native British plant, contains at least nine potentially hepatotoxic pyrrolizidine alkaloids in its leaves and roots. ${ }^{3}$ These alkaloids are less toxic than those in other plants - for example, senecios-which may explain why only a few cases of hepatic veno-occlusive disease caused by ingestion of comfrey are known (G Nicholson and C C J Culvenor, personal communications) and only one has been published. ${ }^{4}$ This second published case is the first to result from a native British plant. The prognosis for our patient remains uncertain for

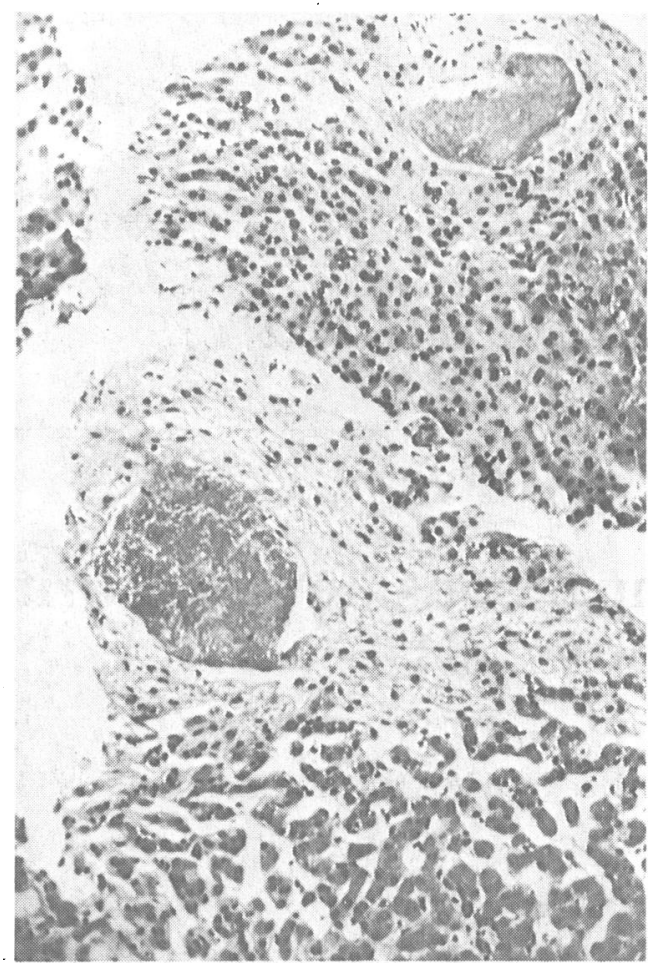

Two freshly thrombosed centrilobular veins in liver biopsy with intimal thickening, sinusoidal distension, and loss of centrilobular hepatocytes. Haematoxylin and eosin.

although about half of Jamaican patients with acute hepatic veno-occlusive disease recovered completely, the remainder died or developed cirrhosis. ${ }^{5}$ Malnutrition and poor health may be risk factors in Jamaica so our patient may have been susceptible to hepatic veno-occlusive disease from comfrey because of his underlying inflammatory bowel disease. ${ }^{5}$

This report serves as a reminder that herbal as well as orthodox medications may have serious side effects.

1 Bras G, Brandt K-H. Vascular disorders. In: McSween RNM, Anthony PP, Scheuer PJ, eds. Pathology of the liver. Edinburgh: Churchill Livingstone, 1979:315-34.

2 Katzka DA; Saul SH, Jorkasky D, Sigal H, Reynolds JC, Soloway RD. Azathioprine and hepatic veno-occlusive disease in renal transplant patients. Gastroenterology 1986;90:446-54.

3 Smith LW, Culvenor CCJ. Plant sources of hepatotoxic pyrrolizidine alkaloids. 7 Nat Prod $1981 ; 44: 129-52$.

4 Ridker PM, Ohkuma S, McDermott WV, Trey C, Huxtable RJ. Hepatic veno-occlusive disease associated with the consumption of pyrrolizidine containing dietary supplements. Gastroenterology 1985;88:1050-4.

5 Stewart KL, Bras G. Veno-occlusive disease of the liver. Qf Med 1957;26:291-315.

(Accepted 15 April 1987)

University Departments of Medicine and Pathology, Bristol Royal Infirmary, Bristol BS2 8HW

C F M WESTON, MB, MRCP, medical registrar B T COOPER, MD, MRCP, lecturer in medicine J D DAVIES, MD, FRCPATH, senior lecturer in pathology

West Cornwall Hospital, Penzance, Cornwall TR18 2PF

D F LEVINE, MD, MRCP, consultant physician

Correspondence to: Dr Cooper. 